\title{
Reflexia biedermeieru v slovenskej literárnej historiografii Miloslav Vojtech
}

\author{
VOJTECH, M.: Biedermeier in Slovak Literary Historiography \\ SLOVENSKÁ LITERATÚRA, vol. 68, 2021, no. 5, pp. 479-494 \\ DOI: https://doi.org/10.31577/slovlit.2021.68.5.1 \\ ORCID ID: 0000-0002-5377
}

Key words: Slovak literature,

Biedermeier, literary historiography, periodization of literature

The article provides an insight into the conceptualisations of Biedermeier in Slovak literary historiography from the 1930 s to the present day. It maps the process of establishment of the term in literary-historical discourse in the first half of the 2oth century and points out the role German Literary Studies played in it. The article analyses the transformation of the term adopted from German literary theory in the 1930s and 1940s. In these decades, M. Pišút and A. Mráz applied Biedermeier to the study of Slovak literature. They identified features of this style - alongside the dominant Classicism and the early Romanticism -in several literary works and authorial styles. In the latter half of the 2oth century, Biedermeier was researched by S. Šmatlák, V. Marčok, and J. Noge. The article also touches upon typological definition of Biedermeier in Slovak poetry and fiction of the 19th century, the relationship of this style with pre-Romantic and Romantic literature, the revitalisation of Biedermeier in the second half of the 19th century, and current research that focuses on Biedermeierian configurations of Realism and looks for its origins in pre-1815 texts.

Klúčové slová: slovenská literatúra, biedermeier, literárna historiografia, periodizácia literatúry 

ermín biedermeier ako pomenovanie istých špecifických typologických čŕt slovenskej literatúry 19. storočia, ktorý sa už dávnejšie stal pevnou súčastou dejín výtvarného i úžitkového umenia, sa začal v slovenskej literárnej historiografii znovu intenzívnejšie presadzovat' najmä od devät'desiatych rokov 20. storočia. Stimulatívne v tomto smere pôsobila najmä česká literárna historiografia, ktorá po roku 1989 tento pojem nielen opätovne vzkriesila k životu, ale rozšírila výrazne jeho záber a zbavila ho ideologizujúcich výkladov minulosti, ktoré ho zjednodušene chápali ako výraz doby, ked',ešte plne vládol katolicizmus ako ideologická opora poslednej vývojovej fázy feudálneho absolutizmu, rozkladaného už prudkým rozvojom kapitalistických peňažných vztahov" (Táborská 1983: 24). Biedermeier sa pokladal jednostranne najmä za odraz hospodárskeho a sociálneho vzostupu stredných vrstiev, ako synonymum „filisterstva, ale zároveň aj útulnosti, pohody a pokoja rodinného prostredia uzavretého pred svetom" (Táborská 1983: 24).

Ak podrobne sledujeme výskum biedermeieru v slovenskej literárnej historiografii a proces jeho etablovania v slovenskom literárnohistorickom diskurze, je evidentné, že ide o pojem, ktorý už v dávnejšej minulosti zažival obdobia intenzívneho záujmu a následne núteného nezáujmu či zabudnutia.

Analýza počiatkov výskumu biedermeieru v našom kultúrnom priestore však nie je možná bez zmapovania súvislostí s literárnovednou germanistikou. Ako je známe, pojem biedermeier bol pôvodne posmešným a parodickým označením literárnych a kultúrnych prejavov takzvaných predmarcových čias. Ako prví ho použili Ludwig Eichrodt (1827-1892) a Adolf Kußmaul (1822-1902), ktorí v mníchovských Fliegende Blätter v rokoch 1850 - 1857 vydávali paródie na malomeštiacku poéziu prvej polovice 19. storočia (Sahánek 1938: 8). Vymysleli postavičku učitel'a Gottlieba Biedermeiera, ${ }^{1}$ prostredníctvom ktorej sa vysmievali životným hodnotám predchádzajúcej epochy. Počas druhej polovice 19. storočia sa teda tento pojem spájal predovšetkým s naivným veršovníctvom prvej polovice 19. storočia. Prototypom tohto kultúrneho javu bol vidiecky učitel', ktorý „číta Bibliu, spieva a tvorí verše, ktorých komike nerozumie. Spojuje v sebe dve veci: naivné veršotepectvo a takmer detsky obmedzenú mysel'. Z takto komicky selankovitého učitel'a vidieckej školy niekde vo Švábsku sa stane zástupca pokojnej skromnej doby, stane sa ,nositel'om občianskej kultúry“" (Sahánek 1938: 8-9).

Posmešné a satirické vnímanie predmarcového obdobia v rakúskej a nemeckej literatúre sa začalo pozvol'ne prehodnocovat' po roku 190o. Pomenovanie „biedermeier" bolo postupne zbavené pejoratívneho nádychu a začalo sa používat' ako označenie dobového životného štýlu a módy, neskôr aj výtvarného umenia a literatúry. Následne sa objavili práce, ktoré rehabilitovali a spopularizovali túto epochu. ${ }^{2}$ Začali živé diskusie o biedermeieri, ktoré vyvrcholili v tridsiatych

1 Sémantika tohto mena sa vysvetluje rôzne. Najčastejšie sa uvádza, že pomenovanie vzniklo ironickým spojením dobovo módneho výrazu „Biederkeit“ (čestnost) s bežným nemeckým priezviskom Meier. Niektoré interpretácie dodávajú, že adjektívum „bieder“ (cnostný, počestný) vo význame latinského „virtus“ bolo najmä v rakúskej oblasti vel'mi časté, a odkazujú na jeho frekvenciu napríklad v bardskej poézii viedenského osvietenca Michaela Denisa. Iná hypotéza uvádza, že toto pomenovanie vzniklo spojením mien dvoch seriálových postavičiek z časopisu Fliegende Bläter, Biedermanna a Bummelmaiera, do tretej zloženiny - Biedermeier (podrobnejšie Tvrdík 2015: 100).

2 Napríklad Hermann 1913, Boehn 1911, Houben 1924. 
rokoch 20. storočia. Ani výskum biedermeieru sa však nevyhol dobovým politickým okolnostiam. Ako uvádza Ehrhard Bahr,

„biedermeierovské bádanie v súlade so svojimi konzervatívnymi východiskami a podporované predstavami tretej ríše sa sústredilo iba na tú literárnu tendenciu obdobia reštaurácie, ktorá bola viditel'ná u Mörikeho, Drosteovej, možno aj u Grillparzera a iste aj u Stiftera, no určite však nebola prítomná u Heineho, Börna a mladonemcov. V znamení zbožnej rezignácie sa ako oblúbené témy biedermeierovskej literatúry osvedčili lúbostné odriekania a poslušná vernost', spätost' s prírodou a vlastou, materské štastie, úcta k starobe a to, čo bolo s oblubou označované ako, služba čistému bytiu'; ide teda o rýdzo ,nemecké' cnosti, ktoré vychádzali skôr z ducha vlastnej doby. Pod vplyvom stále silnejúceho ideologizovaného záujmu o ,svetový názor' zaostávala analýza literárneho štýlu za propagáciou biedermeierovského, životného pocitu““ (Bahr 2006: 337).

Práve v tridsiatych rokoch 20. storočia vyšlo viacero zásadných prác, ktoré stimulovali výskum biedermeieru aj v slovenskej literárnej historiografii. Potrebné je uviest' predovšetkým prácu Wilhelma Bietaka Der Lebensgefül des „,Biedermeiers “ in der österreichischen Dichtung (1931), ktorá do literárnej histórie uviedla pojem „biedermeierovského životného pocitu“, a štúdiu Hermanna Pongsa Ein Beitrag zum Dämonischen im Biedermeier (1935), ktorá uvažuje dokonca o tragickom a démonickom biedermeieri.

Na výskumy v oblasti rakúskej a nemeckej literatúry koncom tridsiatych rokov 20. storočia vel'mi bezprostredne reagovala aj vtedajšia československá germanistika a čoskoro sa odrazili tiež v oblasti literárnovednej slovakistiky. Výskum otázok biedermeieru u nás teda siaha už do obdobia pred druhou svetovou vojnou a je spojený s Filozofickou fakultou Univerzity Komenského v Bratislave. Práve na jej pôde vznikla práca popredného českého germanistu Stanislava Sahánka (1883 -1942) ${ }^{3}$ Literární biedermeier v nèmeckém písemnictví (1938), ktorá inšpirovala d'alšie výskumy problematiky v oblasti literárnovednej slovakistiky i bohemistiky. S. Sahánek vo svojej práci zhrnul dovtedajšie germanistické výskumy o otázkach biedermeieru a podal „prvý ucelený po česky písaný prehl'ad o novom stredoeurópskom umenovednom a literárnom fenoméne“ (Tvrdík 2015:107). Postupne sa venuje výkladu a genéze pojmu biedermeier v literárnej histórii, jeho periodizačnému vymedzeniu, typologickým znakom, vztahu literárneho biedermeieru k iným druhom umenia a napokon výberovo aj charakteristike troch reprezentatívnych osobností biedermeieru, ktoré majú synekdochicky zastupovat' „tri hlavné druhy básnické“ (Sahánek 1938: 28): Eduarda Mörikeho (1804-1875) ako reprezentanta lyriky, Franza Grillparzera (1791 - 1872) ako predstavitel'a drámy a Adalberta Stiftera (1805-1868) ako poprednú osobnost' biedermeierovskej prózy. S. Sahánkovi sa v tejto práci podarilo v komprimovanej podobe zachytit' nielen dovtedajší stav biedermeierovského bádania a podobu diskusie k tejto otázke v nemeckej a rakúskej literárnej vede na sklonku tridsiatych rokov 20. storočia, ale zároveň predstavit' a definovat' literárny biedermeier ako komplexný literárnohistorický

3 S. Sahánek pôsobil na Filozofickej fakulte Univerzity Komenského v Bratislave ako docent germanistiky v rokoch 1934 - 1940. Tragicky zahynul v koncentračnom tábore Mauthausen. 

jav a jeho prejavy demonštrovat' na biograficko-interpretačných sondách do literárnej tvorby niekol'kých autorov.

V tom istom roku, v ktorom bola publikovaná Sahánkova kniha o biedermeieri v nemeckom písomníctve, vychádza aj rozsiahla monografia profesora dejín slovenskej literatúry na bratislavskej filozofickej fakulte Milana Pišúta Počiatky básnickej školy Štúrovej (1938). Práve v tejto práci sa po prvý raz v slovenskej literárnej historiografii použil termín biedermeier ako označenie istých osobitostí literárnej produkcie tridsiatych rokov 19. storočia. V rámci precíznej, v duchu tainovského pozitivizmu koncipovanej analýzy spoločensko-politických pomerov v Uhorsku pred rokom 1848 sa M. Pišút pokúsil aj o literárnosmerovú analýzu obdobia tridsiatych rokov 19. storočia, v ktorom identifikoval povedla klasicizmu a popri prehlbujúcej sa subjektivizácii poézie, záujme o folklór a počiatkov romantizmu i biedermeierovské tendencie, čím slovenský literárny život ukotvil do literárnoestetických súradníc stredoeurópskeho kultúrneho priestoru „predmarcového obdobia“, a to komparatívnym poukázaním na paralely s literárnou situáciou v českých krajinách a Rakúsku. V súvislosti s výskumom literárnych smerov prvej polovice 19. storočia M. Pišút dokonca hovorí o potrebe zmeny metodologického postoja. Konštatuje, že „dnes máme k literárnym smerom iný pomer. Predstavujú nám určité slovesné tendencie, ale ich menší alebo väčší význam závisí od rýchlosti sociálnych pohybov vo svete" (Pišút 1938:16). Biedermeier v týchto intenciách vníma ako „slovesný smer“, ktorý „najlepšie zodpovedá obdobiu československej poézie od rokov 1820 do 1840" (Pišút 1938:16-17). Reaguje aj na najnovšie impulzy rakúskej a nemeckej literárnej historiografie, dokonca hovorí o dobovo aktuálnej snahe preniest' označenie „biedermeier“ do literárnej histórie. Inšpiruje sa prácou W. Bietaka Das Lebensgefühl des „Biedermeier“ in der österreichischen Dichtung, odkial' preberá charakteristiku a typologické vymedzenie biedermeierovskej literatúry, najmä poézie. Upozorňuje na Bietakom vymedzené ústredné témy básnictva, ktoré možno zhrnút' pod heslo: umenie, samota, sen, láska a štastie. Okrem toho zdôrazňuje aj biedermeierovskú úctu k štátu a jeho zachovaniu, „spokojnost' v najvyššie prípustných potrebách svojho stavu“ (Pišút 1938: 17), akcentuje dôraz na pokoj a poriadok v rámci celej spoločnosti a biedermeierovský ideál spojenia človeka s prírodou a Bohom.

O slovenskom biedermeieri uvažuje M. Pišút v intenciách slovensko-rakúskych medziliterárnych súvislostí: „Vzhl'adom na to, že Viedeň v tých rokoch bola nielen politickým, ale aj kultúrnym centrom ríše, môžeme bezpečne sledovat' duchovné a estetické prúdenie, ako sa šírilo z Viedne do prebúdzajúcich sa literatúr jednotlivých národností, a teda i do diel slovenských, najmä ked'Slováci mali do Viedne vel'mi blízko“ (Pišút 1938: 17). Pripomína, že „rakúsky biedermeier nebol zjavom izolovaným na kultúrny okruh Viedne“ (Pišút 1938: 18). Postupne analyzuje širšie spoločensko-politické okolnosti genézy biedermeieru, hl'adá jeho súvislosti s prebúdzajúcimi sa ohlasmi ludovej piesne ${ }^{4}$ či aktualizáciou hovorovej reči. Za tvorcov biedermeierovskej poézie pokladá okruh básnikov českých Květov, zo Slovákov sem radí Samuela Godru, Gašpara Fejérpatakyho, Samuela

4 V súvislosti so záujmom o folklór M. Pišút pripomína, že ,ohlasy ludovej poézie tvorili v biedermeierskom období jeho dôležitú súčast', ale boli tiež jeho protikladom, lebo pripravovali v syntéze s romantizmom nové obdobie českej a najmä slovenskej literatúry“ (Pišút 1938: 22). 
Tomášika, Sama Chalupku, Augusta Horislava Škultétyho a zaraduje sem aj viaceré prvotiny „mladých štúrovcov“. Do okruhu autorov slovenského básnického biedermeieru začleňuje tiež Karola Kuzmányho s jeho básnickou skladbou Běla (1836). Podl'a Pišúta predstavuje typ básnického textu, z ktorého vanie „túha po kludnom živote, odpor proti honbe za slávou a blahobytom“ (Pišút 1938: 20). Celkovo vnímal biedermeier ako „tiché obdobie vzrastu, dozrievania, prípravy na prahu 19. storočia a vlastnej národnej literatúry“ (Pišút 1938: 24), teda chápal ho ako prológ k romantickej epoche, a zároveň funkčne, ako „účinnú propagandu v mestskom prostredí, ktorá mala sústredit' český a slovenský živel“" (Pišút 1938: 24). Z literárneho a estetického hl'adiska upozornil na primárne poučný a zábavný charakter súdobej biedermeierovskej literárnej produkcie.

$\mathrm{V}$ priebehu štyridsiatych rokov 20. storočia uviedol termín biedermeier najmä do českej literárnej histórie literárny historik a germanista Vojtěch Jirát $(1902-1945)^{5} \mathrm{v}$ antológii Lyrika českého obrozeni $(1750$ - 1850) z roku 1940 a v štúdii Erben čili Majestát zákona (1944). V slovenskej literárnej historiografii ho po M. Pišútovi použil v štyridsiatych rokoch literárny historik a kritik Andrej Mráz, najskôr v článku Dr. Anton Ottmayer, ktorý bol publikovaný v mesačníku Elán (Mráz 1940: 5-7), ${ }^{6}$ a následne v dejinách slovenskej literatúry, písaných po nemecky, ktoré vyšli pod názvom Die Literatur der Slowaken v roku 1943. Kým M. Pišút vo svojej monografii vymedzil platnost' pojmu biedermeier predovšetkým pre oblast' slovenskej poézie tridsiatych rokov 19. storočia, A. Mráz ho, naopak, posunul do oblasti umeleckej prózy a použil ho v súvislosti s prozaickou tvorbou predstavitel'a mladšej bernolákovskej generácie A. Ottmayera, ktorá bola publikovaná v almanachu Zora. A. Mráz upozornil najmä na žánrovú, tematickú a štýlovú rôznorodost' textov publikovaných v almanachu, ktorý podla neho ,jasne odráža vtedajšiu slovenskú literárnu situáciu“ (Mráz 1943: 58). Akcentoval skutočnost', že sú v ňom zastúpené vedl'a textov vytvorených v prísnom klasicistickom duchu a textov s osvietensko-racionalistickým a didaktickým zameraním aj texty, ktoré predstavujú jediný „rýdzi typ slovenského literárneho biedermeieru“ (Mráz 1943: 58) viedenskej proveniencie.

5 V. Jirát sa ako prvý z českých germanistov zapojil do prebiehajúcich diskusií o biedermeieri už v priebehu tridsiatych rokov 20. storočia, a to v príspevku z roku 1937, ktorý napísal po francúzsky, Le rôle du „Biedermeier“ dans le réveil Tchèque (Jirát 1937: 10-12). Text bol neskôr po česky publikovaný v knihe Portréty a studie (Jirát 1978: 548-551).

6 A. Mráz tu polemizuje najmä s nelichotivými a príkro formulovanými hodnoteniami prozaickej tvorby A. Ottmayera v staršej literárnej historiografii, reprezentovanými najmä postojom Jaroslava Vlčka, podla ktorého bol tento prozaik „známy primitívnymi novelistickými pokusmi zo Zory“ (Vlček 1933: 368). V článku, ktorého primárnym cielom bolo ,upozornit na zabúdaného bernolákovského prozaika, sčiastky rehabilitovat' jeho torzovité beletristické dielo a najmä správnejšie ho zaradit do vývinových súvislostí našej a súčasnej európskej literatúry“ (Mráz 1940: 6), ponúka A. Mráz jedno z prvých detailnejších interpretačných nahliadnutí do Ottmayerových prozaických textov v dejinách slovenskej literárnej historiografie: , ak v nemeckej literatúre, a to najmä v jej časti rakúskej, slovesné plody z epochy 1815 - 1848 označujú sa termínom biedermeier, tak práce Ottmayerove v našom literárnom kontexte výrazne a typicky odzrkadlujú znaky tejto slovesnej štruktúry“ (Mráz 1940: 5). Za Ottmayerove spojivá s biedermeierom považuje útek pred dramatickým napätím čias do sveta citov, hladanie rovnováhy medzi individuálnym životom a spoločenskou angažovanost'ou, zobrazovanie zátiší harmonického rodinného života, hladanie „strateného raja srdca“, ale najmä tematickú, fabulačnú, štylistickú a žánrovú spätost's rakúskym biedermeierom. Interpretačnými sondami do jednotlivých textov sa d'alej pokúša túto tézu potvrdit' a spresnit'. 

dza, že v slovenskej literatúre sa vyskytuje jednak v období pred romantizmom, ale aj v období neskorého romantizmu, teda v porevolučných rokoch. Je zaujímavé, že biedermeieru nevenuje ani zmienku v súvislosti so slovenskou poéziou tridsiatych rokov 19. storočia. Na margo emblematického diela slovenského básnického biedermeieru, Kuzmányho Běly, poznamenáva len to, že ide o text zjavne inšpirovaný Goetheho idylickým eposom Hermann a Dorothea (Mráz 1943: 104).

V roku 1948 vydáva A. Mráz svoje dejiny aj v slovenskej verzii, a to hned v dvoch vydaniach: ako štrnásty zväzok edície Vlastivedná knižnica Slovenskej akadémie vied a umení a spolu s Dejinami spisovnej slovenčiny Eugena Paulinyho ako piaty diel Slovenskej vlastivedy. V súvislosti s biedermeierom tu mierne rozvinul a rozšíril najmä svoje konštatovania o Ottmayerovej próze. Ottmayera považuje za jediného bernolákovca, ktorý pestoval umeleckú prózu, a dodáva, že celé ovzdušie jeho „prozaických útvarov, ich kompozičné a štylistické maniery ukazujú, že učený budínsky právnik prišiel do styku so súvekou rakúskou biedermeierovskou prózou a jej vlastnosti transplantoval $\mathrm{k}$ nám, citovou roznežnenostou chváliac a propagujúc občianske cnosti, životnú vyrovnanost' a pohodlie, múdrosti, ktoré sa l'akajú bojov a napätí. Do farbotlačovo krehkých farieb premalúval Ottmayer i fakty zo svojej prítomnosti, prostredie i l'udí z okolia Žiliny“ (Mráz 1948:124). Na záver dodáva, že „pred vystúpením štúrovcov próza Ottmayerova má najviac čŕt biedermeierovských, ktorej vlastnosti znova ožijú v slovenskej literárnej tvorbe v rokoch matičných“ (Mráz 1948: 124). Naznačuje teda akési pokračovanie biedermeieru v postromantickom období, no v kapitole venovanej takzvaným matičným rokom už túto tézu d'alej nerozvija a bližšie nekonkretizuje. Okrem toho oproti nemeckej verzii svojich dejín A. Mráz podrobnejšie reflektuje aj Kuzmányho básnickú skladbu Běla. Na jednej strane vynecháva svoje pôvodné konštatovanie o Běle ako texte zjavne inšpirovanom Goetheho Hermannom a Dorotheou, skôr akcentuje jej ukotvenost'v slovenskom prostredí a súvekom živote a tiež vlastenecké motívy a výstavbu sujetu retardovanú vkladaním spevov a balád. Okrem toho (na rozdiel od staršej nemeckej verzie svojich dejín) dodáva, že „celé ovzdušie skladby a jej veršová štruktúra sú ešte daňou predchádzajúcej slovesnej štruktúre so životnou náladou biedermeierovskou“ (Mráz 1948: 156).

Ako dokazujú práce M. Pišúta a A. Mráza, v tridsiatych a štyridsiatych rokoch 20. storočia došlo $\mathrm{k}$ uvedeniu pojmu biedermeier do slovenského literárnohistorického diskurzu, no toto označenie malo svoje limity v podobe pomerne malého počtu autorov a literárnych textov, na ktoré ho bolo možné aplikovat'. Príčiny treba hladat' najmä v absentujúcom širšom materiálovom výskume, ako aj v rozkolísanosti vnímania samotného pojmu biedermeier vo vtedajšej literárnej vede. Už v prácach z tridsiatych a zo štyridsiatych rokov 20. storočia vidíme v chápaní tohto pojmu dve výrazné tendencie: na jednej strane snahu uvažovat' o biedermeieri ako o samostatnom „literárnom obdobi“ “ či „slovesnom smere“ (M. Pišút), ktorá korešponduje s tendenciami najmä v rakúskej a sčasti aj v nemeckej literárnej histórii konštruovat' biedermeier ako svojbytnú „,literárnu epochu“, na druhej strane však zostáva vnímanie biedermeieru skôr ako odrazu istého ,životného pocitu“ (A. Mráz).

Po roku 1948 sa výskum týchto otázok v slovenskej literárnej histórii akoby načas zastavil. Súviselo to jednak s meniacou sa geopolitickou situáciou, 
so stratou kontaktov so západoeurópskym literárnovedným prostredím, ale tiež 485 s ideologickým obratom $v$ názoroch na biedermeier ako literárny a kultúrny jav. Marxistická literárna história vnímala biedermeier ako úpadkový kultúrny, umelecký a literárny jav spätý najmä s reakčným meštianstvom, ako produkt buržoáznej kultúry, ktorá stála v opozícii voči dobovo preferovanej kategórii ludovosti v umení a literatúre. ${ }^{7}$

K problematike biedermeieru sa v druhej polovici pätdesiatych rokov 20. storočia v súvislosti s básnickou skladbou K. Kuzmányho Běla vrátil literárny historik Stanislav Šmatlák. V štúdii Poznámky k vývinu slovenskej epickej poézie I. Klasicistická epika zasadil interpretáciu Kuzmányho Běly do širších súvislostí autorovho estetického a filozofického uvažovania a detailne analyzoval východiská, ktoré tvoria konštrukciu jeho básnického sveta, výrazne obmedzeného na „srdce človeka" a založeného na dokonalej harmónii ludských vztahov. Kuzmányho básnický svet a jeho hodnotový systém interpretoval S. Šmatlák ako „výraz únavy meštianstva nielen z revolúcie, ale aj z vel'kých napoleonských vojen, otriasajúcich na začiatku 19. stor. Európou“ a Bělu označil za najcharakteristickejší prejav biedermeieru ako „meštianskeho duchovného prúdenia u nás“ (Šmatlák 1957:33). V súvislosti s termínom biedermeier pripomenul, že ho do slovenskej literatúry uviedol M. Pišút v práci Počiatky básnickej školy Štúrovej, no na druhej strane mu vytkol istú jednostrannost' chápania daného pojmu. Na prístupe M. Pišúta prekážalo S. Šmatlákovi najmä to, že nehodnotil biedermeier ,ako duchovný výraz konkrétnej sociálnohistorickej situácie“ (Šmatlák 1957:33), ale videl v ňom najmä „tiché obdobie vzrastu, dozrievania, prípravy na prahu 19. storočia a vlastnej národnej literatúry“ (Pišút 1938: 24), teda prológ k takzvanej vlastnej „štúrovskej epoche“.

Pri hodnotení biedermeieru ako literárneho a umeleckého javu sa S. Šmatlák nevyhol dobovo podmienenému ideologizujúcemu nazeraniu, ked'vnímal biedermeier ako ,ideový názor“, ktorý bol „odrazom relatívnej zaostalosti hospodársko-spoločenského vývinu“, „,bol ideológiou nerozvinutého, s feudalizmom zmiereného meštianstva, ktoré si svoju predstavu o ideálnom usporiadaní spoločnosti oprelo jednak o ideál dobrého, spravodlivého samovládcu, jednak o všel'udské mravné cnosti, za ktorých nositel'a pokladalo samo seba" (Šmatlák 1957:33). Biedermeier sa teda podla neho prezentuje skôr ako kultúrny jav „triedne“ viazaný na meštiansku spoločenskú vrstvu a stojaci v opozícii voči marxistickou historiografiou preferovanej kategórii „l'udovosti“, ako jav, ktorý nemohol vyhovovat' „revolučnejším náladám štúrovcov“ (Šmatlák 1957: 33). Prínosom Šmatlákovho uvažovania o slovenskom biedermeieri (aj ked'ho obmedzil iba na oblast' poézie a v jej rámci len na jednu, hoci pomerne rozsiahlu básnickú skladbu) je, že hovorí o potrebe konštituovat' „slovenský biedermeier - teda básnické dielo Kuzmányho z tridsiatych rokov“ ako „osobitnú, relatívne samostatnú vývinovú kvalitu, ktorá bude neskorším vývinom popretá “(Šmatlák 1957:33), teda nemožno ho chápat' iba ako obdobie prípravy, respektíve prechodu od klasicizmu $\mathrm{k}$ romantizmu. Túto koncepciu biedermeieru neskôr prezentoval aj v neskorších syntetických literárnohistorických prácach Dve storočia slovenskej lyriky (1979),

7 Okrem toho ,určité pochybnosti vzbudzovala (a tento názor pretrváva) prevažujúca interpretácia z hl'adiska ,životného pocitu' (Bietak) či ,svetového názoru', lebo bol vo fašistickej ére germanistiky (Pongs, Petersen) zneužitý v duchu nacionálnosocialistickej ideológie“ (podrobnejšie Tvrdík 2015: 112). 
Dejiny slovenskej literatúry od stredoveku po súčasnost'(1988) a napokon v Dejinách slovenskej literatúry II. (1999).

Koncom pätdesiatych rokov teda S. Šmatlák terminologicky vymedzil platnost' pojmu biedermeier pre oblast' slovenskej obrodeneckej poézie. V oblasti literárnohistorického výskumu umeleckej prózy tridsiatych rokov 19. storočia bola však situácia odlišná. Názor A. Mráza o súvislosti Ottmayerových próz s rakúskym biedermeierom slovenská historiografia druhej polovice 20. storočia už d'alej výraznejšie nerozvíjala. Preferovala skôr termín sentimentálna próza a od konca šest'desiatych rokov, predovšetkým vd'aka monografii Viliama Marčoka Počiatky slovenskej novodobej prózy (1968), najmä pojem „preromantizmus“. V. Marčok v tejto práci na margo Mrázovej úvahy o súvislosti Ottmayerových próz s rakúskou biedermeierovskou literatúrou kriticky podotkol, že ide o „zúžené chápanie literárnohistorického procesu. Zúžené v tom zmysle, že nebral na vedomie celé literárne ovzdušie, v ktorom najmä v prechodných obdobiach hrajú významnú úlohu periférne literárne javy“ (Marčok 1968: 204). Mrázovo konštatovanie teda V. Marčok vnímal pomerne úzko, reflektoval ho iba na pozadí dobovej problematiky autorstva, ked' originálnost' nebola priamou podmienkou kvality literárneho textu, a snažil sa skôr poukázat' na väzby Ottmayerovej novelistiky $\mathrm{s}$ domácou literárnou tradíciou, pričom na medziliterárne súvislosti nazeral ako na sekundárne. Marčokova preferencia pojmu „preromantizmus“ súvisí najmä s jeho príklonom k metodologickým východiskám francúzskej literárnej komparatistiky (Paul van Tieghem, Daniel Mornet) a k tradícii českého štrukturalizmu, predovšetkým k metodologickému odkazu Felixa Vodičku a jeho práce Počátky krásné prózy novočeské (1948).

Literárnosmerový obraz slovenskej literatúry tridsiatych rokov 19. storočia sa tak začal výrazne terminologicky komplikovat'. Dôkazom je aj kapitola s názvom Poézia v koncepcii a diele Karola Kuzmányho, ktorá je súčastou knihy Dve storočia slovenskej lyriky. S. Šmatlák v nej doplnil svoje zistenia z roku 1957, svoju interpretáciu Kuzmányho Běly posunul do nových súvislostí a konfrontoval ju s aktuálnym literárnohistorickým výskumom. Nepriamo naznačil, že výskum literárnej situácie tridsiatych rokov 19. storočia sa v slovenskej literárnej vede terminologicky sproblematizoval. Pripomenul potrebu definovat' prechodné obdobie medzi klasicizmom a romantizmom ako relatívne samostatnú vývinovú kvalitu, ktorú v súvislosti s Kuzmányho Bělou označil ako biedermeier. Neopomenul dodat', že to isté obdobie vymedzil ako relatívne samostatné vývinové obdobie V. Marčok v práci Počiatky slovenskej novodobej prózy, pričom „pre označenie tohto obdobia si zvolil termín ,preromantizmus““(Šmatlák 1979:57). S. Šmatlák dokonca aj sám znejasnil (oproti svojej štúdii z roku 1957) obsah pojmu biedermeier: tu ho vníma ako synonymum k pojmu „,sentimentalizmus“ (Šmatlák 1979:56), respektíve označuje ho ako „sentimentalistickú korektúru klasicizmu“ (Šmatlák 1979: 57).

Situáciu v literárnohistorickej reflexii obdobia tridsiatych rokov 19. storočia teda komplikovala terminologická neustálenost' jednak samého pojmu „biedermeier“, ale najmä jeho časté splývanie s „konkurenčným“ termínom „sentimentalizmus“ a najmä „preromantizmus“, ktorý od šest'desiatych rokov 20. storočia výraznejšie preferovala aj slovenská literárna historiografia a pokúšala sa o jeho 
typologické vymedzenie. ${ }^{8}$ Príčiny tohto terminologického „chaosu“ pramenia jednak v synkretickom charaktere slovenskej literatúry prvej polovice 19. storočia, no najmä v oneskorovaní prijímania viacerých literárnych tendencií a smerov slovenskou literatúrou. Ak by sme mali uvedené literárnohistorické kategórie v slovenskej literatúre vzájomne oddelit' a hierarchizovat' $z$ hl'adiska chronologického a komparatívne vymedzit' vo vztahu k iným národným literatúram, vidíme, že preromantizmus v dejinách západoeurópskych literatúr logicky predchádza romantizmu a časovo sa vyskytuje už v druhej polovici 18. storočia, romantizmus tu zaznamenávame približne v prvých dvoch decéniách 19. storočia a biedermeier nastupuje (v nemeckom a rakúskom literárnom prostredí) až po roku 1815, teda je javom postromantickým. Slovenskú literatúru zasahujú biedermeierovské vplyvy približne v rovnakom čase ako v rakúsko-nemeckom prostredí, ale vzhladom k oneskorovaniu základných literárnych tendencií-klasicizmu a preromantizmu - je biedermeier v slovenskom literárnom kontexte primárne javom predromantickým, čo spôsobuje jeho stotožňovanie s preromantizmom (vd'aka mnohým spoločným typologickým prvkom neraz opodstatnené). Pre porovnanie je potrebné uviest', že napríklad v blízkej českej literatúre, kde romantizmus nastupuje približne o jedno desatročie skôr ako na Slovensku, česká literárna história (v posledných desatročiach zameraná na intenzívny výskum otázok biedermeieru) ${ }^{9}$ zasa konštatuje napätie princípov biedermeieru a romantizmu. ${ }^{10}$

Opätovné zintenzívnenie záujmu o výskum otázok biedermeieru v slovenskej literárnej histórii zaznamenávame postupne od devät'desiatych rokov 20. storočia. Dá sa pozorovat'v dvoch aspektoch: jednak v rozšírení jeho platnosti na väčší počet textov slovenskej literárnej produkcie tridsiatych a štyridsiatych rokov 19. storočia, no takisto v posunutí jeho tradičných literárnohistorických medzníkov najmä za rok 1850, ale aj pred rok 1815 .

Rozšírenie platnosti pojmu biedermeier na väčší počet literárnych textov tridsiatych a štyridsiatych rokov 19. storočia úzko súvisí najmä s revíziou chápania preromantizmu v podobe, v akej ho pre oblast' slovenskej umeleckej prózy vymedzil predovšetkým V. Marčok na konci šest'desiatych rokov 20. storočia. Korpus prozaických textov, ktoré V. Marčok v monografii Počiatky slovenskej novodobej prózy nediferencovane označil za preromantické, môžeme jemnejšie typologicky diferencovat' na tri špecifické typy.

Prvý typ možno označit ako primárne preromantický. Táto skupina textov sa vyznačuje akcentovaním citovosti pred racionalitou, zameraním na vyššie estetické funkcie, slovanskú ideu alebo nacionálnu problematiku a hlbšie filozofické témy. Tento typ prózy reprezentuje najmä románový pokus K. Kuzmányho

8 Okrem V. Marčoka tento termín pre súbor textov slovenskej predromantickej prózy použil aj Július Noge v monografii Slovenská romantická próza (Noge 1969: 26-85).

9 Spomedzi vel'kého množstva prác na túto tému možno spomenút napríklad práce Dalibora Turečka (Tureček 1996a, Tureček 1996b, Tureček 2003, Tureček 2018) a Radmily Hrdinovej (Hrdinová 1997). 10 Otázke napätia biedermeieru a romantizmu sa venujú napríklad Janáčková 1998 a Tureček 2005, Tureček 2018. 
488 Ladislav (1836), Kollárova autobiografická a memoárová próza Paměti z mladšich let života (1863) ${ }^{11}$ a novela Jána Bolemana ${ }^{12}$ Jelka (1835).

Druhú skupinu textov možno vymedzit' ako biedermeierovský typ prózy. Reprezentuje ho najmä bohatá novelistická produkcia tridsiatych rokov 19. storočia. Biedermeierovské novely sú situované do idylizovaných krajín, prírodných scenérií, komorného prostredia meštianskych domácností, ale aj exteriérov slovenských mestečiek a miest, vyznačujú sa jednoduchými, sentimentálne ladenými príbehmi, vyrovnanými charaktermi postáv, prejavujú túžbu po dôverne známom pokoji domova a rodinného kruhu, nakol'ko rodina a rodinné zväzky sú pre biedermeier najposvätnejšou hodnotou, ktorá je overená stáročnou tradíciou. Novely plnia najmä zábavnú a výchovnú funkciu, ich výchovné posolstvo akcentuje predovšetkým krestanské hodnoty a mravnost'. Do tejto skupiny môžeme zaradit' prózy S. Godru, A. Ottmayera a Martina Sucháňa.

Ako tretiu možno vyčlenit' skupinu textov, ktoré v sebe syntetizujú témy a postupy preromantického i biedermeierovského typu prózy. Reprezentuje ich románový fragment Pavla Jána Tomáška Obchodníci s podtitulom Povídka z nových časův vydaný po česky v roku 1846. Obchodníci nesporne patria k jedinečným literárnym dielam dokumentujúcim hl'adanie nových ciest slovenskej prózy prvej polovice 19. storočia. Ide o prózu, ktorá sa pokúsila vniest' do slovenskej literatúry nové a aktuálne témy, prispela k prekonávaniu sentimentálnych schém, a čo je najdôležitejšie, vniesla do slovenskej literatúry nový prvok - zobrazenie mestského (respektíve vel'komestského) prostredia, vd'aka čomu ju možno považovat za prvú prózu mestského typu v slovenskej literatúre. S preromantickým typom prózy spája Tomáškových Obchodníkov predovšetkým tematizácia myšlienky slovanskej vzájomnosti a otázok národnostných pomerov v Uhorsku, ako aj vztah k európskej preromantickej literatúre: próza je uvedená mottom $\mathrm{z}$ dobovo populárneho románu anglického spisovatel'a Olivera Goldsmitha (1728 - 1774) Wakefieldský farár (1764), ktoré anticipuje príbeh aj ideové východiská Obchodníkov. Tomášek sa charakterom svojej prózy síce výrazne vzdialil od prototypu biedermeierovskej sentimentálnej novely, reprezentovanej najmä textami A. Ottmayera, no s biedermeierom spája jeho Obchodníkov množstvo tematických, motivických a ideových prvkov. ${ }^{13}$

Ak uvažujeme o rozšírení platnosti pojmu biedermeier na väčšiu skupinu textov tridsiatych a štyridsiatych rokov 19. storočia, nemožno obíst' súdobú dramatickú produkciu, reprezentovanú najmä Jánom Chalupkom. Teatrologička

11 Táto autobiografická a memoárová próza vyšla knižne po autorovej smrti v roku 1863, no vznikala postupne od polovice tridsiatych rokov 19. storočia.

12 Novelu publikoval J. Boleman pod pseudonymom A. Palucký.

13 Primárnym typologickým znakom Obchodníkov, ktorý najcelistvejšie odráža biedermeierovskú kultúrnu atmosféru, je ústredný topos mesta. Jeho použitie zarad'uje tento text vôbec k prvým výsostne „mestským“ prózam v slovenskej literatúre. Tomášek sa vo svojej próze nevyhýba ani dobovo populárnym moralisticko-didaktickým sentenciám. Moralisticko-didaktický rozmer má Tomáškov dôraz na náboženstvo a vieru v Boha ako najvyššiu autoritu a zdôrazňovanie princípov krestanskej etiky, ale aj vyzdvihovanie tradičných a biedermeierovskou kultúrou preferovaných cností, ako sú láska k rodičom, striedmost', skromnost', láska k vlasti a národu, ale rovnako sa tu môžeme stretnút aj s prezentáciou konzervatívnych politických postojov, ku ktorým patrí odpor voči radikalizmu a reformám. S biedermeierom súvisí aj množstvo idealizovaných typov postáv a tradičných tematických a epických prvkov, napríklad konverzačné meštianske salónne scény či sentimentalizovaný obraz plesu. 
Zdenka Pašuthová sa v doslove k prvému zväzku edície divadelných hier J. Cha- 489 lupku z roku 2012 podrobne zaoberá aj ich medziliterárnymi súvislostami. Okrem tradičných zdrojov Chalupkovej dramatiky podnetne uvažuje o jej vztahoch s dobovou biedermeierovskou literárnou produkciou. Tieto súvislosti nachádza už v prvej Chalupkovej hre Kocúrkovo (1830). Identifikuje tu skupinu postáv-rodinu učitel'a Procházku, ktorej hodnotový systém a jej príslušníci „prezrádzajú chvílkovú spätost' Chalupku s estetikou biedermeieru a sentimentálnou meštianskou drámou. Rodinu tvorí konvenčná dvojica otca a dcéry, pre ktorých najvyššiu autoritu predstavuje Boh" (Pašuthová 2012: 486). Koncept postavy L'udmily ako ideálnej a poslušnej dcéry i perspektívnej manželky sa približuje stvárneniu postáv v Kuzmányho Běle a k typom ženských hrdiniek z Ottmayerových noviel. Oproti tomuto idealizovanému a konvenčnému rodinnému prostrediu však J. Chalupka postavil model rodiny Jánoša Tesnošila, ktorý, naopak, predstavuje svet pokrivenej morálky, absencie skutočných hodnôt a deformovaných rodinných vztahov. Tesnošilova rodina ako protipól konvenčných rodinných modelov, kde namiesto „múdreho otca“ dominuje „nemúdra žena“ a deti sú skôr obrazom neschopnosti svojich rodičov a ich nenaplnených ambícií, predstavuje výrazný prvok, ktorým dramatik prostredníctvom satiry a karikatúry relativizuje dobové biedermeierovské sentimentálne schémy v slovenskej literatúre. Z. Pašuthová dokonca v tejto súvislosti uvažuje o Chalupkových hrách takzvaného kocúrkovského cyklu ako o ,antibiedermeierovskej idyle“. Chalupkove hry teda dokazujú, že obluba biedermeierovského „životného pocitu“, idealizovaného sveta biedermeirovských konvencií a harmonizujúcich predstáv o živote, zažíva v slovenskej literatúre tridsiatych rokov nielen obdobie vzostupu, ale súčasne sa stáva aj predmetom satiry a výraznej hodnotovej relativizácie.

Ako už bolo naznačené, záujem literárnej histórie o biedermeier môžeme pozorovat' nielen v rozšírení jeho platnosti na väčší počet textov slovenskej literárnej produkcie tridsiatych a štyridsiatych rokov 19. storočia, ale aj v snahách o posunutie jeho tradičných literárnohistorických medzníkov najmä za rok 1850, respektíve pred rok 1815. S. Šmatlák o slovenskom biedermeieri uvažoval ako o samostatnej vývinovej kvalite, ktorú bude musiet' „nasledujúci romantizmus zásadne prekonat"“ (Šmatlák 1979: 57). Novšie literárnohistorické výskumy však naznačujú, že nastupujúci slovenský romantizmus biedermeier skôr nekonfliktne absorboval. Niektoré biedermeierovské relikty pretrvali aj v slovenskej próze raného romantizmu. Biedermeierovsky podfarbenej štylizácii sa nevyhol napríklad Jozef Miloslav Hurban v cestopise Cesta Slováka k bratrům slavenským na Moravě $a v$ Čechách (1841). Príkladom biedermeierovskej ornamentálnej štylizácie je opis rodinnej atmosféry u Pospíšilovcov v Hradci, ktorý nápadne pripomína scény z Kuzmányho Bělyi Ottmayerových noviel:

„Boli práve raňajky. Tam bol Jaroslav, tu Bohuslav, na druhom boku stola pani Pospišilová, pri ktorej rozprával vtipný a štebotavý Vašek, a hned'nato prikvitla spanilá ruža domu Marie, naša známa poetka z Květov [...] Pri dome pána Pospíšila je utešená, pekná záhradôčka ako malý raj. Sú tu georgíny, ruže a iné rozličné dietky Flóry. Na spodku záhradky, rozloženej na návrší, je pekná besiedka, krytá viničom a košatým stromovím. Počas môjho tunajšieho pobytu za jedného utešeného večera sa tu zabávala malá spoločnost'. Slečinka Marie pri gitare spievala české 
Táto biedermeierovská ornamentalizácia však vyznieva v kontexte celého cestopisu už iba ako falošná dekoratívna štylistická hra, za ktorou sú prítomné či dokonca sú ňou prekryté „pocity skepsy a nesplnených nádeji““ (Káša 2001: 145) nastupujúcej romantickej generácie. Biedermeier na Slovensku sa teda nedostal (na rozdiel od situácie v susednej českej literatúre) do napätia s nastupujúcim romantizmom, ale skôr naopak, romantizmus ho plynule absorboval a jeho relikty sa sporadicky objavovali najmä v literárnych textoch príslušníkov takzvanej pragmatickej línie slovenského romantizmu. Biedermeierovský substrát je napríklad markantný aj v emblematickej lyricko-epickej básnickej skladbe slovenského romantizmu - v Detvanovi Andreja Sládkoviča z roku 1853, ako na to poukázala Irena Bilińska v doslove k vydaniu diela A. Sládkoviča (Bilińska 2014: 731-749) ${ }^{14}$ a v štúdii Biedermeier Andreja Sládkoviča (Bilińska 2019:149-162). Podl'a I. Bilińskej „priestor pre biedermeierovský aspekt diela ponúka synkretizmus tejto skladby na úrovni žánrovej, štylistickej a druhovej, ako aj využívanie prvkov príznačných pre epiku a lyriku, obohatených o dramaticko-divadelnú stránku“ (Bilińska 2014: 736). K biedermeieru odkazuje Sládkovičov Detvan najmä svojou žánrovou štruktúrou (prvky idylického eposu) a zameraním na mikrosvet hlavného hrdinu, pre ktorého je typická vyrovnanost's existujúcim spoločenským poriadkom, rezignácia na rozorvanost', heroické gestá či vzburu. Biedermeierovské črty nadobúda aj zobrazenie prírody ako intímneho domova, ako „útulnej tváre vlasti“, s ktorou je hrdina v symbióze a duševnej rovnováhe, rovnako i láska hlavných protagonistov Martina a Eleny, ktorá nie je tragickou romantickou láskou, ale „pokojným, stálym, priam manželským citom" (Bilińska 2014:738).V intenciách biedermeierovských epických schém je konštruovaný aj záver vyznačujúci sa harmóniou a mravným optimizmom. Podl'a I. Bilińskej „Detvan, ako idylický epos a do istej miery aj protipól básnikovej Maríny, vytváral predstavu čitatel'sky požadovanej ,zázračnej obyčajnosti'. Jeho šlachetný, verný, nebojácny, ale aj jednoduchý a poctivý hrdina plne zodpovedá požiadavkám biedermeierovského diela na plnenie terapeuticko-tešitel'skej funkcie“ (Bilińska 2014: 739-740). ${ }^{\mathbf{1 5}}$

Už S. Sahánek v monografii Literární biedermeier v německém písemnictví poukázal na skutočnost', že biedermeier presahuje aj cez revolučný rok 1848, ktorý sa tradične považuje za koniec biedermeierovskej epochy (Sahánek 1938: 7, 49-53). Ďalší z českých teoretikov biedermeieru, literárny historik a germanista V. Jirát, v tejto súvislosti hovorí o neskorom biedermeieri (Jirát 1940). Najnovšia slovenská literárna história o neskorom biedermeieri uvažuje napríklad $\mathrm{v}$ súvislosti s literárnymi textami, ktorých charakter je nezlučitelný s koncepciou realizmu konca 19. storočia. $\mathrm{K}$ takýmto autorkám patrí podl'a literárnej historičky Marcely Mikulovej prozaička Terézia Vansová. V súvislosti s častou Vansovej prozaickej tvorby hovorí:

14 Podobne aj Peter Zajac považuje Sládkovičovho Detvana za „vrchol historizujúceho biedermeieru“ (Zajac 2016: 59).

15 V tejto súvislosti odkazuje I. Bilińská na prácu Dobrochny Ratajczakowej (Ratajczakowa 2006: 233-248). 
„V podstate však všetky charakteristické znaky biedermeieru zo začiatku 19. storočia - rodina ako posvätná hodnota, domácnost', záhrada, idylickost', láska k vlasti, krestanské hodnoty, mravnost', beletria ako výchova a zábava - opakujú sa u Vansovej na konci storočia, pretože politické a spoločenské okolnosti, za akých sa pôvodne tento smer sformoval, nepominuli, ale ostávajú aktuálne. To, čo sa mohlo zdat'v próze Jána Pavla Tomáška Obchodníci (1846), považovanej za slovenský prejav biedermeieru, ako idealizovaná fikcia, to je u Vansovej zažitá realita“ (Mikulová 2016:190).

T. Vansová teda na konci 19. storočia revitalizovala a univerzalizovala tie hodnoty biedermeierovskej kultúry a literatúry, ktoré sa aj v tomto období javili ako nadčasové, a to najmä ideál harmonickej a kultivovanej rodiny stojacej proti nástrahám civilizovaného sveta a biedermeierovský ideál činorodého človeka, ktorý stelesňovala aj sama autorka. Revitalizácie biedermeieru v tvorbe T. Vansovej a v kontexte slovenského literárneho realizmu zároveň reprezentujú „konfigurácie realistického diskurzu s prvkami biedermeieru“ (Taranenková 2016: 67). Tieto biedermeierovské konfigurácie možno (okrem tvorby T. Vansovej) identifikovat' aj v románoch Eleny Maróthy Šoltésovej a v literárnych textoch Pavla Országha Hviezdoslava a Svetozára Hurbana Vajanského, „kde sa realizujú prostredníctvom motívu rodiny predstavujúcej azyl v nepriazni spoločenských a politických podmienok, respektíve ako základnej jednotky národného života“ (Taranenková 2016: 67).

Koncept neskorého biedermeieru v slovenskej literatúre, ktorý sa včleňuje do širšieho syntetického obrazu procesov v slovenskej literatúre konca 19. storočia, súvisí so širším chápaním tejto literárnohistorickej kategórie, ktorá biedermeier poníma viac univerzalisticky, nadčasovo, a chápe ho ako niečo viac než literárnu epochu alebo literárny smer, skôr ako životný postoj, existenčnú formu či metódu, „ktorú nemožno jednoznačne ohraničit' smerom do minulosti ani budúcnosti“" (Exner 1995: 21). Posúvanie platnosti literárnohistorického pojmu biedermeier mimo jeho tažiska, ktoré literárna história tradične kládla medzi roky 1815-1848, čiže na autorov a literárne texty druhej polovice 19. storočia, ktoré korelujú so základnými spoločenskými a s umelecko-estetickými hodnotovými postojmi biedermeieru, súvisí v slovenskej literárnej historiografii do istej miery s úsilím „dekonštruovat““ už dlhodobo neudržatel'ný „panrealistický“ koncept vývinu slovenskej literatúry druhej polovice 19. storočia, no ukazuje aj na to, že nadčasový hodnotový svet biedermeierovskej kultúry, ktorý zrodilo „predmarcové obdobie“, zažíval série svojich revitalizácií aj hlboko v druhej polovici 19. storočia.

Okrem posunu platnosti pojmu biedermeier do druhej polovice 19. storočia sa môžeme stretnút aj s úvahami posunút počiatky biedermeieru pred rok 1815 , teda pred tradičný počiatok biedermeieru v rakúsko-nemeckom kultúrnom prostredí. V tejto súvislosti napríklad literárna historička Eva Fordinálová píše o osobitnej „,slovenskej ceste k biedermeieru ešte skôr, ako sa v plnosti rozvinul po napoleonských vojnách v Nemecku“ (Fordinálová 2009: 239), a o jeho počiatkoch uvažuje v súvislosti s poéziou Juraja Palkoviča a Bohuslava Tablica. Podla E. Fordinálovej „poézia oboch autorov zo sociálno-historického i estetického hl'adiska naznačuje určitý posun zo šl'achtického' rokoka k biedermeieru, k meštianskemu, ,občianskemu rokoku'. Je to poézia pre tretí stav, pochopitel'ne, u nás najmä pre 

inteligenciu z neho pochádzajúcu“" (Fordinálová 2009: 239). Na margo Tablicovej básne Oda na dub, publikovanej v prvom zväzku Poezyí z roku 1806, ako aj celej Tablicovej básnickej tvorby E. Fordinálová poznamenáva, že má „korene barokové, kmeň klasicistický, korunu otvárajúcu sa z rokoka do biedermeieru“ (Fordinálová 2008:159). Týmito slovami naznačuje isté typologické a literárnohistorické súvislosti neskoršej biedermeierovskej literatúry. Už S. Sahánek konštatoval, že biedermeier má svoje duchovné korene hlboko v nemeckej minulosti, najmä v nemeckom baroku (bližšie Sahánek 1938: 15). Za spojivá s barokom pokladá motívy zbožnej obce, počestnosti nemeckého domu, akcent na poctivost' a hlas svedomia. Oproti tomu biedermeierovská túžba po ludskej dokonalosti, zmysel pre nadosobnú povinnost', oslava práce a pracovitosti zasa vykazujú spoločné črty s témami osvietenskej a klasicistickej literatúry, a napokon - a to treba zdôraznit - biedermeierovský idylizmus má svoje korene práve v rokoku.

V. Jirát v tejto súvislosti zasa hovorí o biedermeieri ako o literárnom fenoméne, „v ktorom sa zliali rôzne smery, často i protikladné“, pričom „jeho jednota je zaručená nie estetickým programom, ale náladou a kultúrou doby. Tá príznačne zafarbuje všetky prvky, ktoré biedermeier prijal od starších alebo súčasných hnutí, a to duchom meštianskym" (Jirát 1940: nepaginovaný úvod). Ako jeden z prameňov biedermeierovskej „nálady“ uvádza práve rokokovú tradíciu. Podla Jiráta biedermeier odkazuje na rokoko „chválou spokojnosti a občianskych i rodinných radostí, chválou jednoduchého života a priemernosti. Idylickost' životného názoru je podoprená horáciovskou vyrovnanost'ou citu a rozumu“ (Jirát 1940: nepaginovaný úvod). Na druhej strane, „od skutočného rokoka sa však odlišuje jednoduchostou, nezáludnostou a nedvojzmyselnost'ou, naivitou, vel'akrát nepredstieranou, a cudnostou“ (Jirát 1940: nepaginovaný úvod). Úvahy E. Fordinálovej o „skorej slovenskej ceste“ $\mathrm{k}$ biedermeieru preto možno vnímat' skôr ako hladanie prameňov tohto literárneho javu, ako úvahu, ktorá potvrdzuje kontinuitu neskorých prejavov literárneho rokoka v slovenskej literatúre s neskoršími prejavmi biedermeieru, ktorá je zároveň prejavom kontinuity rôznych podôb idylizmu v slovenskej literatúre 19. storočia.

Analýza doterajšej reflexie biedermeieru v slovenskej literárnej historiografii ukazuje, že vnímanie tohto pojmu osciluje medzi dvomi modelmi, ktoré majú svoje korene už v počiatočnom štádiu uvažovania o tomto stredoeurópskom kultúrnom a umeleckom fenoméne. Na jednej strane je tu viditel'ná snaha pevnejšie uchopit' biedermeier ako typologicky definovatel'nú a chronologicky vymedzitel'nú literárnu tendenciu, ktorá je súčastou synkretického modelu slovenskej literatúry tridsiatych rokov 19. storočia, ked' koexistuje paralelne s prejavmi vrcholného klasicizmu a s preromantizmom, a následne je v štyridsiatych a pätdesiatych rokoch 19. storočia absorbovaná romantizmom. Na strane druhej sa však môžeme stretnút's vnímaním biedermeieru ako „životného pocitu“, univerzalisticky a nadčasovo chápanej kategórie, teda s chápaním, ktoré umožňuje uvažovat'o biedermeierovských ideových či tematických vrstvách aj v literárnych textoch druhej polovice 19. storočia. 
HURBAN, Jozef Miloslav, 1960. Cesta Slováka k slovenským bratom na Morave a v Čechách 1839. Bratislava: Slovenské vydavatel'stvo krásnej literatúry.

\section{Literatúra}

BAHR, Ehrhard, 2006. Dějiny německé literatury 2. Od osvicenstvík době predbřeznové. Praha: Karolinum. ISBN 80-246-1017-5.

BIETAK, Wilhelm, 1931. Der Lebensgefül des „Biedermeiers“ in der österreichischen Dichtung. Wien: Braumüller.

BILIŃSKA, Irena, 2014. Romantický básnik slobody. In SLÁDKOVIČ, Andrej. Dielo. Bratislava: Kalligram-Ústav slovenskej literatúry SAV, s. 731-749. ISBN 978-80-8101-858-9.

BILIŃSKA, Irena, 2019. Biedermeier Andreja Sládkoviča. In ZAJAC, Peter-SCHMARCOVÁ, Lubica, ed. Slovenský romantizmus. Synopticko-pulzačný model kultúrneho javu. Brno: Host, s. 149-162. ISBN 978-80-7491-545-1.

BOEHN, Max von, 1911. Biedermeier. Deutschland von 1815 - 1847. Berlin: Cassirer.

Estetika, časopis pro estetiku a teorii umění, 1996. [Monotematické číslo k otázkam biedermeieru.] Roč. 33, č. 3-4, s. 1-127. ISSN 0014-1291.

EXNER, Milan, 1995. Biedermeier a syndrom rozpadu. Estetika, roč. 32, č. 2, s. 15-23. ISSN 0014-1291.

FORDINÁLOVÁ, Eva, 2008. Problematika a problémy slovenskej klasicistickej poézie. Trnava: Vydavatel'stvo Trnavskej univerzity. ISBN 978-80-8082-193-7.

FORDINÁLOVÁ, Eva, 2009. Klasicizmus. In SEDLÁK, Imrich, ed. Dejiny slovenskej literatúry I. Martin: Matica slovenská - Bratislava: Literárne informačné centrum, s. 180-311. ISBN 978-80-7090-935-5.

HERMANN, Georg, 1913. Das Biedermeier im Spiegel seiner Zeit. Briefe, Tagebücher, Memoiren. Volksszenen und ähnliche Dokumente. Berlin - Leipzig - Wien - Stuttgart: Deutsches Verlagshaus Bong \& Co.

HOUBEN, Heinrich Hubert, 1924. Der gefesselte Biedermeier. Literatur, Kultur, Zensur in der guten alten Zeit. Leipzig: H. Haessel.

HRDINOVÁ, Radmila, 1997. Václav Kliment Klicpera a český biedermeier. In Východočeské Athény a Josef Liboslav Ziegler. Boskovice: Albert, s. 140-145. ISBN 80-85834-50-2.

JANÁČKOVÁ, Jaroslava, 1998. Romantizmus - biedermeier. In Česká literatura od počátků $k$ dnešku. Praha: Nakladatelství Lidové noviny, s. 209-211. ISBN 80-7106-308-8.

JIRÁT, Vojtěch, 1940. Lyrika českého obrození (1750-1850). Praha:Českomoravský kompas. JIRÁT, Vojtěch, 1978. Portréty a studie. Praha: Odeon.

JIRÁT, Vojtěch, 1937. Le rôle du „Biedermeier“ dans le réveil Tchèque. L' Europe centrale, roč. 12 , č. 1, s. 10-12.

KÁŠA, Peter, 2001. Medzi estetikou a ideológiou. Literárnohistorické a komparatistické štúdie. Prešov: Prešovská univerzita.

MARČOK, Viliam, 1968. Počiatky slovenskej novodobej prózy. Bratislava: Vydavatel'stvo SAV. MIKULOVÁ, Marcela, 2016. Vansovej koncept neskorého biedermeieru. In MIKULOVÁ, Marcela-TARANENKOVÁ, Ivana, ed. Konfigurácie slovenského realizmu. Synopticko-pulzačný model kultúrneho javu. Brno: Host, s. 187-195. ISBN 978-80-7491-546-8.

MRÁZ, Andreas, 1943. Die Literatur der Slowaken. Berlin-Prag-Wien: Volk und Reich Verlag. MRÁZ, Andrej, 1948. Dejiny slovenskej literatúry. Bratislava: Slovenská akadémia vied a umení. MRÁZ, Andrej, 1940. Dr. Anton Ottmayer. Elán: Mesačník pre literatúru a umenie, roč. 10, č. 8, s. 5-7.

NOGE, Július, 1969. Slovenská romantická próza. Bratislava: Vydavatel'stvo SAV.

PAŠUTHOVÁ, Zdenka, 2012. Texty-kontexty. In CHALUPKA, Ján. Súborné dramatické dielo I. Bratislava: Divadelný ústav, s. 463-551. ISBN 978-80-89369-51-5.

PIŠÚT, Milan, 1938. Počiatky básnickej školy Štúrovej. Bratislava: Učená společnost Šafaříkova, 1938.

PONGS, Hermann, 1935. Ein Beitrag zum Dämonischen im Biedermeier. Dichtung und Volkstum, roč. 36, č. 2-3, s. 241-261.

RATAJCZAKOWA, Dobrochna, 2006. Arcydzieło biedermeieru? In W krysztale $i$ w ptomieniu. Studia i szkice o dramacie i teatrze 2. Wrocław: Wyd. Uniwersytetu Wrocławskiego, s. 233-248. ISBN 978-83-229-2775-5.

SAHÁNEK, Stanislav, 1938. Literární biedermeier v německém písemnictví. Spisy Filosofické fakulty University Komenského v Bratislavě XXVI. Bratislava: Filozofická fakulta UK. 
494 ŠMATLÁK, Stanislav, 1957. Poznámky k vývinu slovenskej epickej poézie I. Klasicistická epika. Slovenská literatúra, roč. 4, č. 1, s. 3-34.

เo ŠMATLÁK, Stanislav, 1979. Dve storočia slovenskej lyriky. Bratislava: Tatran.

'U TARANENKOVÁ, Ivana, 2016. Konfigurácie slovenského literárneho realizmu. In MIKULOVÁ, Marcela-TARANENKOVÁ, Ivana, ed. Konfigurácie slovenského realizmu. Synopticko-pulzačný model kultúrneho javu. Brno: Host, s. 27-71. ISBN 978-80-7491-546-8.

TUREČEK, Dalibor, 1996a. Biedermeier na českém obrozeneckém jevišti. Estetika, roč. 33, č. 3-4, s. 73-83. ISSN 0014-1291.

TUREČEK, Dalibor, 1996b. Úvodem. Estetika, roč. 33, č. 3-4, s. 1-3. ISSN 0014-1291.

TUREČEK, Dalibor, 2003. Biedermeier a současná literárněvědná bohemistika. Česká literatura, roč. 51, č. 3, s. 289-301. ISSN 0009-0468.

TUREČEK, Dalibor, 2005. Romantismus anebo/kontra biedermeier? Slovenská literatúra, roč. 52, č. 4-5, s. 243-261. ISSN 0037-6973.

TUREČEK, Dalibor, 2018. Sumáŕ. Diskurzivita české literatúry 19. století. Brno: Host. ISBN 978-80-7577-603-7.

TVRDÍK, Milan, 2015. K problematice literatury německého a rakouského biedermeieru. Svět literatury, roč. 25, č. 52, s. 95-115. ISSN 2336-6729.

TÁBORSKÁ, Jiřina, 1983. Biedermeier. In VLAŠÍN, Štěpán, ed. Slovník literárnich směrů a skupin. Praha: Panorama, s. 24.

VLČEK, Jaroslav, 1933. Dejiny literatúry slovenskej. Turčiansky sv. Martin: Matica slovenská. ZAJAC, Peter: Paradoxy slovenského romantického hnutia. In Štúr, štúrovci, romantici, obrodenci. Bratislava: Ústav slovenskej literatúry SAV, s. 33-78. ISBN 978-80-88746-32-4.

Prof. PhDr. Miloslav Vojtech, PhD.

Katedra slovenskej literatúry

a literárnej vedy

Filozofická fakulta Univerzity

Komenského

Gondova 2

81102 Bratislava 1

Slovenská republika

E-mail: miloslav.vojtech@uniba.sk 